\title{
PROPOSAL TO ACHIEVE FLOODPLAIN CONNECTIVITY IN ALȚÂNA SECTOR ON HÂRTIBACIU RIVER (TRANSYLVANIA, ROMANIA)
}

\author{
Răzvan VOICU *, Linda HERON **,

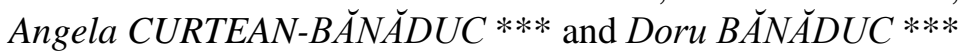

\begin{abstract}
* National Institute of Hydrology and Water Management, București-Ploiești Street 97, București, Romania, rzvnvoicu@yahoo.com,getiiliberi@gmail.com

** Chair, Ontario Rivers Alliance, Ronka Road 379, Worthington, ON, Canada, P0M3H0, linda.heron@rogers.com

*** “Lucian Blaga” University of Sibiu, Applied Ecology Research Center, Dr. Ion Raţiu Street 5-7, Sibiu, Sibiu County, Romania, RO-550012, angela.banaduc@ulbsibiu.ro, ad.banaduc@yahoo.com
\end{abstract}

DOI: 10.1515/trser-2015-0088

KEYWORDS: lotic system, floodplain connectivity, fish conservation.

\section{ABSTRACT}

The process of supplying water to the new anthropogenic wetland is achieved gravitationally, and the excess water in the wetland will be directed towards the Hârtibaciu River in a similar natural way. The fish and fauna of the Hârtibaciu River have a disrupted lateral connectivity due to its banks embanking including in the proximity of the Alţâna locality. The newly proposed anthropogenic wetland would improve habitat quality for the fish species of conservation interest, Rhodeus amarus (Bloch, 1782), and increase its population numbers. A new fish species, Chondrostoma nasus, was identified for the first time in the Hârtibaciu River.

RÉSUMÉN: Propuesta para lograr la conectividad de llanuras inundables para el sector Altana del Río Hartibaciu (Transilvania, Rumania).

El proceso para suministrar agua al nuevo humedal antropogénico se consigue gravitacionalmente, y el exceso de agua en el humedal se dirigirá hacia el río Hârtibaciu de una manera natural similar. La fauna de peces del río Hârtibaciu tiene una conectividad lateral interrumpida debido a sus bancos de embarque incluyendo en la proximidad de la localidad de Alţâna. El humedal antropogénico recientemente propuesto puede mejorar la calidad del hábitat de las especies de peces de interés conservador Rhodeus amarus (Bloch, 1782) y puede aumentar el número de individuos de esta población. Una nueva especie de pez, Chondrostoma nasus, fue identificada por primera vez en el río Hârtibaciu.

REZUMAT: Propunere de realizare a unei conexiuni laterale în sectorul Alţâna pe râul Hârtibaciu (Transilvania, România).

Procedeul pentru alimentarea cu apă a noii zone umede antropice se realizează gravitaţional, iar excesul de apă din zona umedă va fi direcționată spre râul Hârtibaciu într-un mod natural similar. Peștii din râul Hârtibaciu au o conectivitate laterală perturbată datorită malurilor sale îndiguite, inclusiv în proximitatea localității Alţâna. Zona umedă propusă în articol poate îmbunătăți calitatea habitatului pentru speciile de pești de interes conservativ cum ar fi Rhodeus amarus (Bloch, 1782), și poate crește numărul de indivizi ai acestei populații. O nouă specie de peşte Chondrostoma nasus a fost identificată pentru prima dată în râul Hârtibaciu. 


\section{INTRODUCTION}

Floodplain connectivity adds the necessary habitat for conservation target areas, moderates variable regular and irregular categories of disturbance elements, ameliorates groundwater access, ameliorates water and soils, increases sediment depository potential, supplements nutrient flux, disipates flood energy distribution, invigorates riparian and floodplain biocoenoses, and ensures ecosystem functionality, etc. (Schneider-Binder, 2008, 2009; Orlov and Vovk, 2011; Bănăduc et al., 2016)

The Water Framework Directive sets new standards for waters in the European Union, standards that can be achieved, and the deterioration of aquatic and semi-aquatic ecosystems avoided. Only if rivers, floodplains and wetlands are managed with an integrated permanent approach, can a good ecological and hydro-morphological status be achieved (Peacock, 2003).

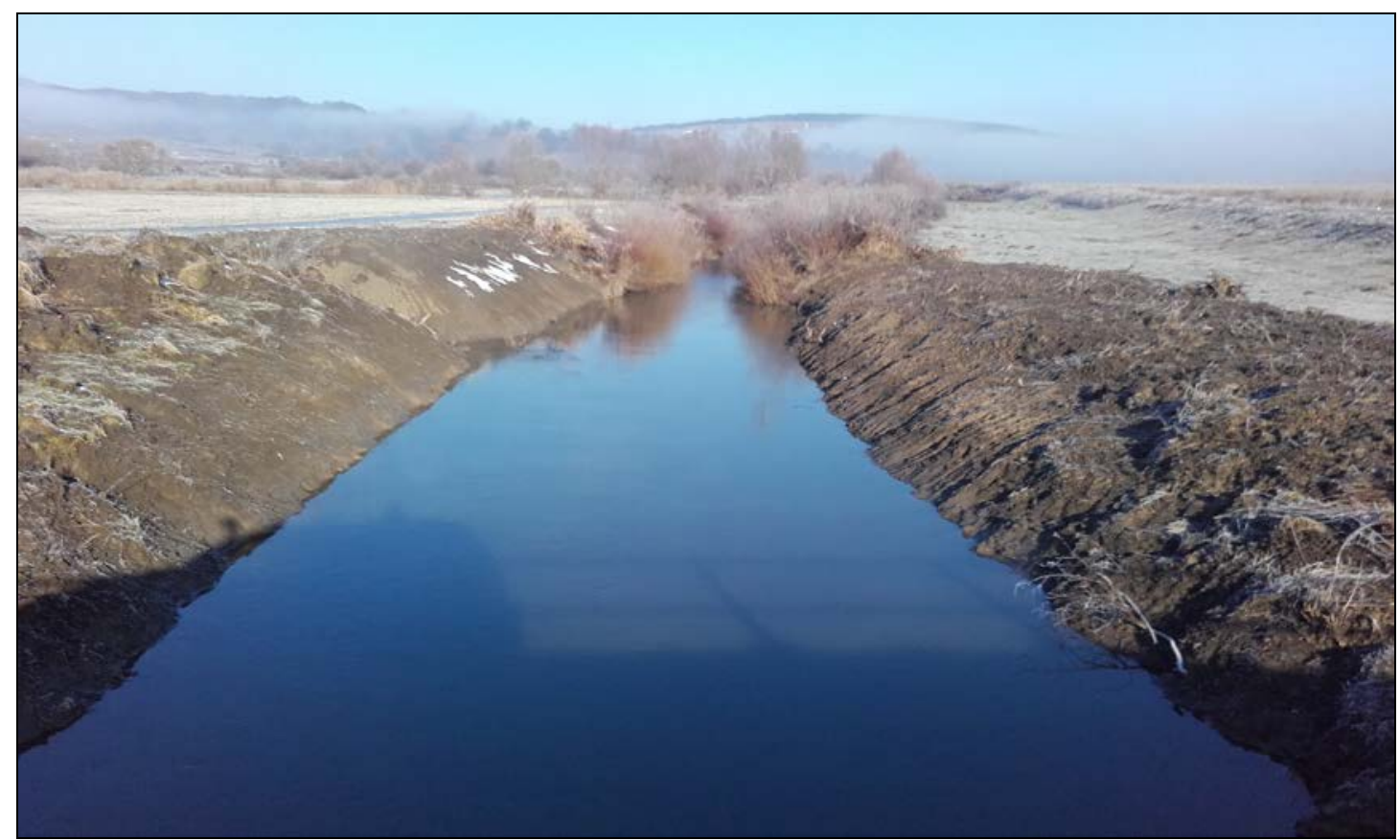

Figure 1a: Human impact on the Hârtibaciu River studied sector on banks and riverbed.

In the study area, the floodplain connectivity was identified as a necessary obtainable outcome, to provide favorable conditions that would meet the goals of restoring connectivity and avoiding/diminishing the present associated challenges/risks, inclusive of the local habitats and biocoenoses, including the fish community.

The proposed wetland creation is more than needed for the local fish and fauna in a sector where the river was chanelised many years ago, and inapropriate work (cleaning the river bed and the river banks with heavy machines, cutting the riverine vegetation, etc.) was carried out (Fig. 1a, b). This sector is very different from the upstream semi-natural sector where fishing takes place (Fig. 2). 


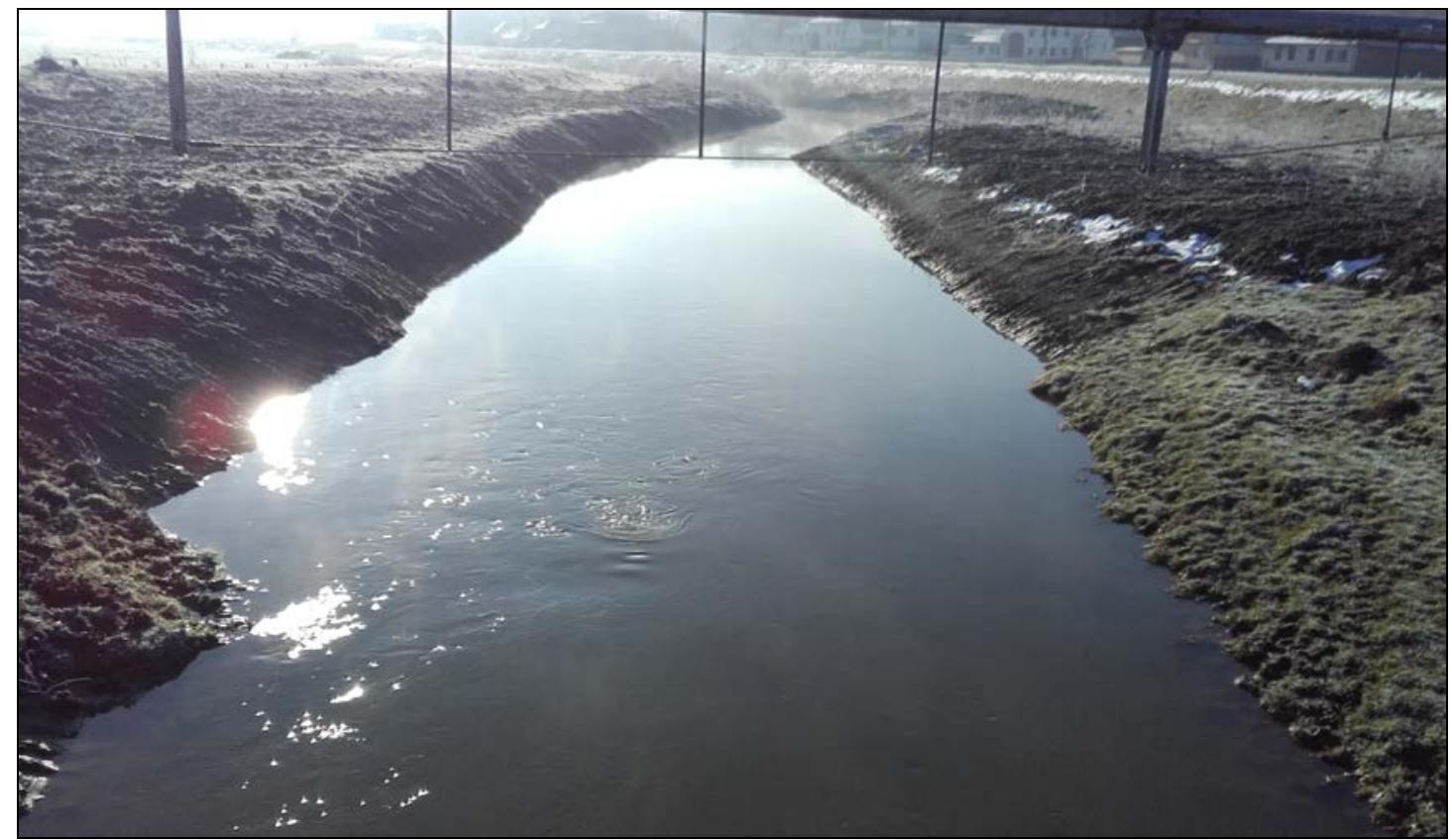

Figure 1b: Human impact on the Hârtibaciu River studied sector on banks and riverbed.

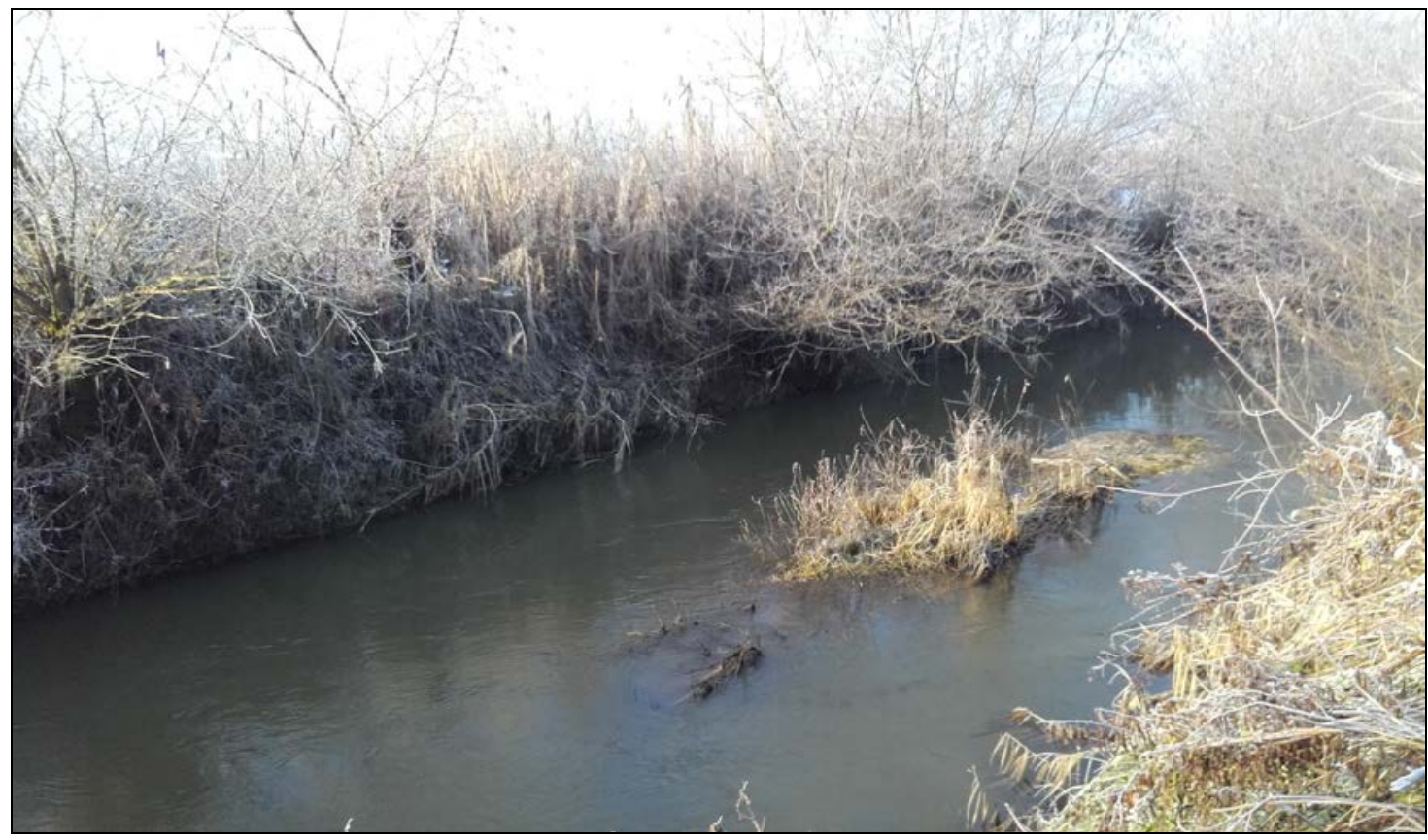

Figure 2: Semi-natural sector of Hârtibaciu River in the studied sector.

\section{MATERIAL AND METHODS}

To assess the need for the proposed investment the fish communities' structure was studied in the local Hârtibaciu River sector, in the Alțâna locality proximity.

The fish individuals were sampled with a mountain fishing net, in time and effort unit, identified and immediately released back into their habitat. 


\section{RESULTS AND DISCUSSION}

\section{Local fish community challenges and need for habitat restoration}

The Hârtibaciu River fish fauna includes a relatively high number of fish species, such as the following: Squalius cephalus (Linnaeus, 1758), Alburnus alburnus (Linnaeus, 1758), Alburnoides bipunctatus (Bloch, 1782), Rhodeus amarus (Bloch, 1782), Gobio obtusirostris Valencienes, 1842, Romanogobio kessleri (Dybowski, 1862), Barbus meridionalis Risso, 1827, Barbatula barbatula (Linnaeus, 1758), Misgurnus fossilis (Linnaeus, 1758), Cobitis taenia Linnaeus, 1758, Sabanejewia romanica (Băcescu, 1943), and Sabanejewia aurata (De Filippi, 1863) (Bănărescu, 1964).

In the Alțâna locality sector of Hârtibaciu River five fish species were sampled: Squalius cephalus, Alburnoides bipunctatus, Chondrostoma nasus (Linnaeus, 1758), Rhodeus sericeus amarus, and Gobio gobio.

In the period of this study Chondrostoma nasus was recorded for the first time in the Hârtibaciu River (Fig. 3).

The creation of the proposed wetland would provide an important buffer zone for fish, especially in the dry and cold (with frozen periods) seasons.

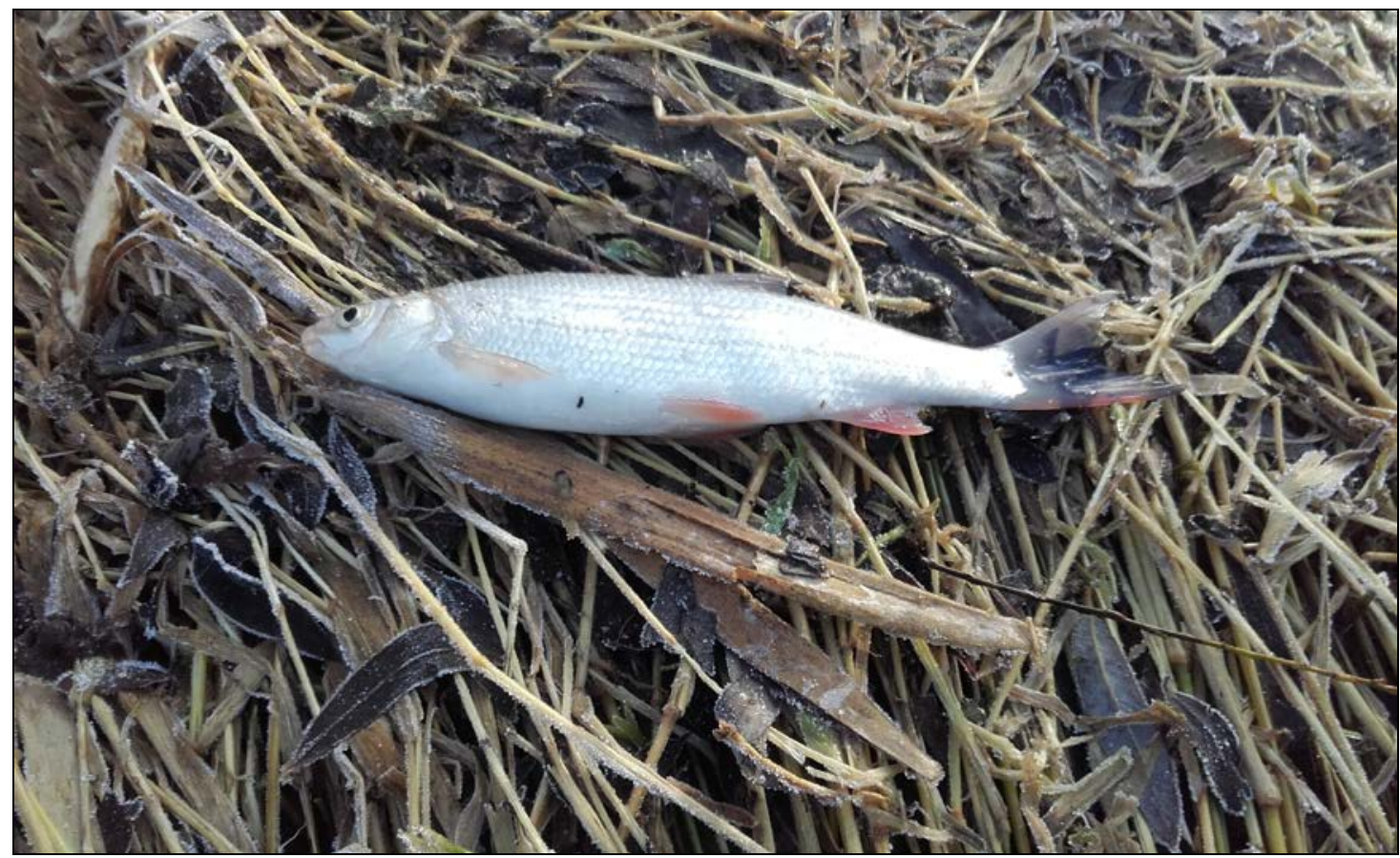

Figure 3: sampled individual of Chondrostoma nasus in the study sector.

In the studied river sector on the Hârtibaciu River only five fish species were recorded: Alburnus bipunctatus with a relative abundance of $40 \%$, Rhodeus amarus $28 \%$, Gobio gobio 20\%, Squalius cephalus 8\%, and Chondrostoma nasus $4 \%$.

The newly proposed wetland area should also be favourable for the colonisation of the bilalve species Anodonta cygnea (Linnaeus, 1758), which is present in the studied water course (Curtean et al., 1999; Sîrbu et al., 1999). This is a species which can provide a symbiotic role for species reproduction of the Rhodeus amarus (Bănărescu and Bănăduc, 2007) and also for the water self-cleaning processes. 
It is also important to note that Rhodeus amarus (Fig. 4) is a protected species under the Habitats Directive (92/43/EEC). The creation of the new proposed wetland can increase its abundance in the area as it provides this species with a habitat characterised by stagnant or semi-stagnant water with soft sediment bottom (Bănărescu and Bănăduc, 2007).

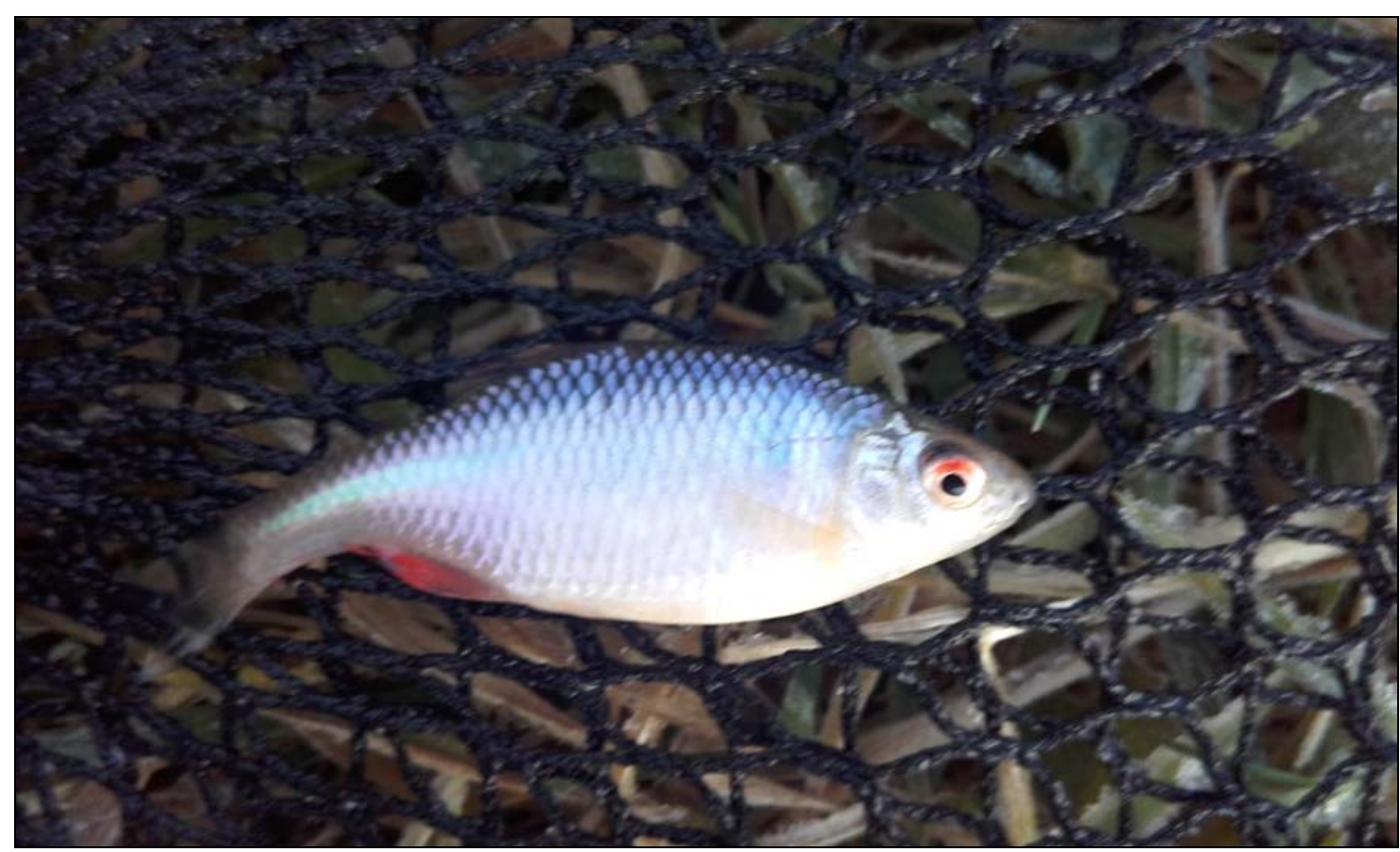

Figure 4: sampled individual of Rhodeus sericeus amarus in the study sector.

The creation of the new proposed wetland can provide a buffer zone for fish, especially in the dry and cold (with long frozen periods) seasons, and also an easy route for passage. Aquatic and semi-aquatic birds, amphibians, mollusks, and aquatic and semi-aquatic vegetation can also benefit by this wetland in the future. It will continue to evolve, becoming stronger and naturally more diverse, healthy and self-supporting over time.

\section{Ecologic restoration and new wetland area creation}

To achieve floodplain connectivity in the study area, we propose the development of a wetland (Fig. 5) downstream of a bridge (Figs. 6a, b) which will be supplied by capturing water from the Hârtibaciu River through a water intake situated upstream of the bridge or upstream from the village of Alțâna.

The wetland to be created is segmented as follows: i) village road capping (upstream), ii) 200 m dyke on the left bank of the Hârtibaciu River, iii) current channel for water discharge protected by the earth dike and, iv) an earth dam to be built on a pasture around $200 \mathrm{~m}$ from the bridge. The earth dikes proposed to be built are trapezoidal with $2.5 \mathrm{~m}$ height, small base of $2.5 \mathrm{~m}$ and large base of $4.0 \mathrm{~m}$ (Figs. 7, 8). 
In order to ensure functionality of the newly created ecosystem, it is recommended that the water level in the wetland will be approximately $1.0 \mathrm{~m}$. Populating the wetland with various native species is recommended, taking into account the species characteristic to aquatic lentic ecosystems with a depth of between $0.8 \mathrm{~m}$ and $1.0 \mathrm{~m}$.

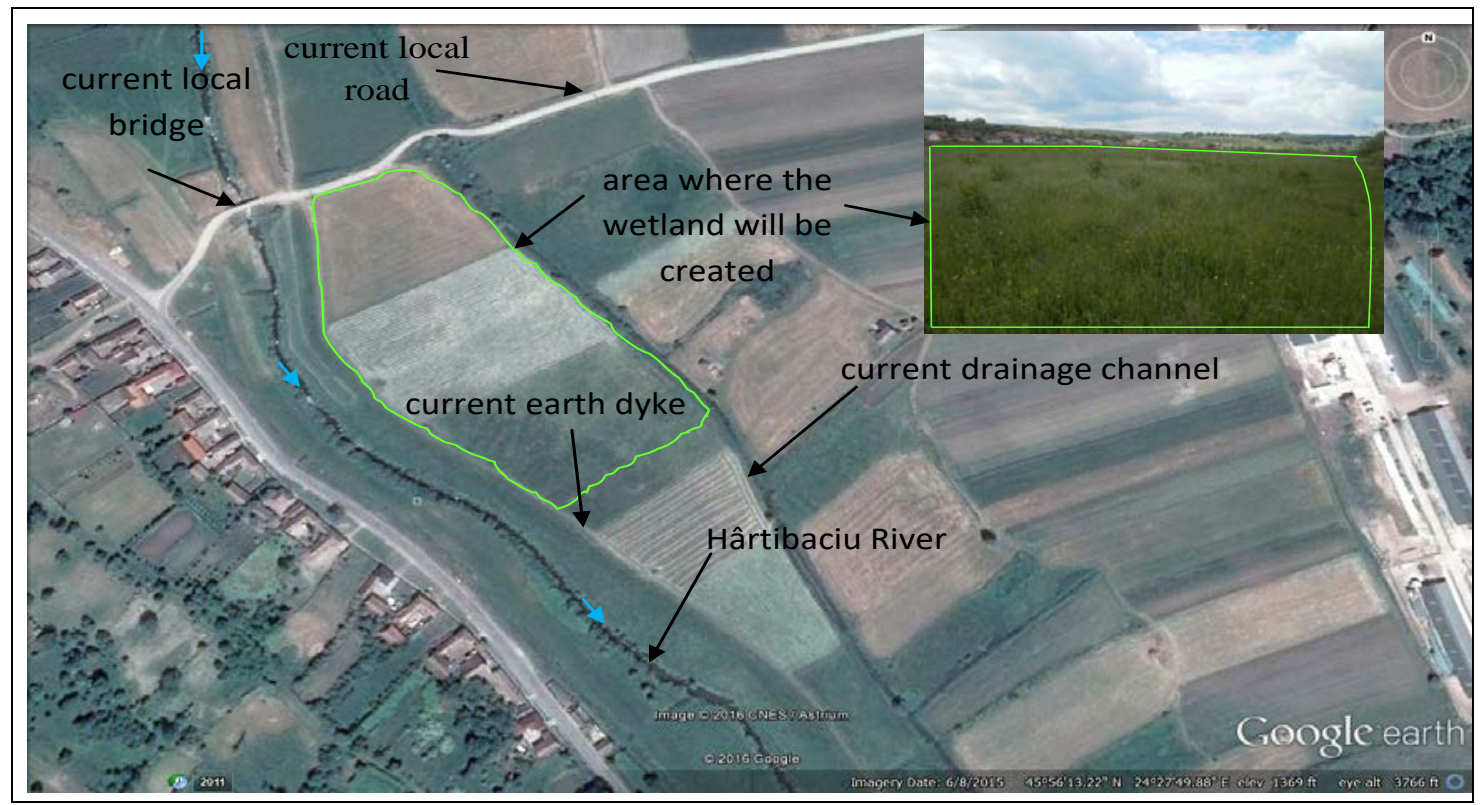

Figure 5: Area where the wetland will be created downstream of bridge (www.google.com).

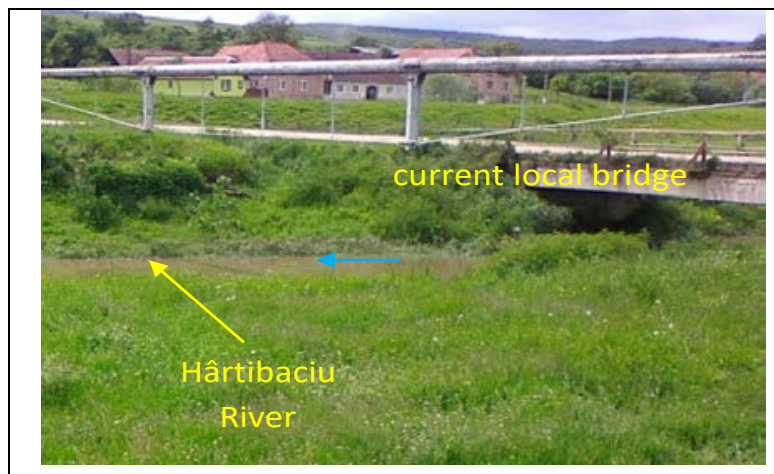

a)

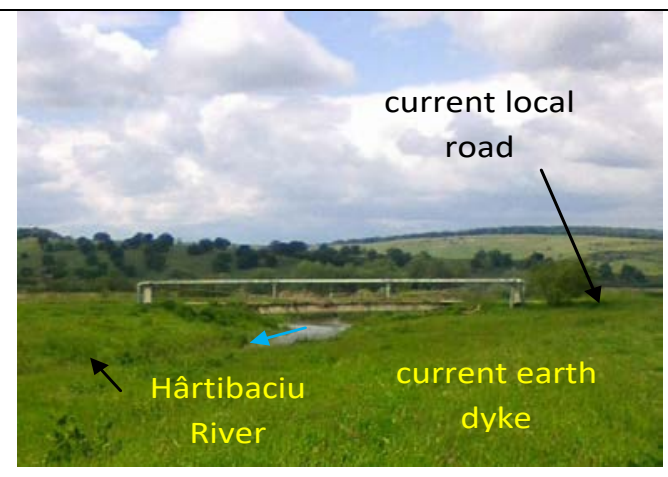

b)

Figure 6: The Hârtibaciu River downstream of the bridge in the village of Alțâna.

\section{Steps in creating the new anthropogenic wetland.}

The first step is aimed at creating habitat conditions that can later support the development of the biotic component (communities of plants and aquatic animals). In this case, in the study area (Figs. 5, 6), it is recommended that the wetland interior is situated near the village of Alțana and its water supply system. 
The second step is the process of populating the wetland with certain species of aquatic organisms (e.g. macrophytes, some species of fish). Thusly, the complexity of interrelations between these two components (biotic and abiotic) will ensure the functionality of the newly created ecological system/wetland.

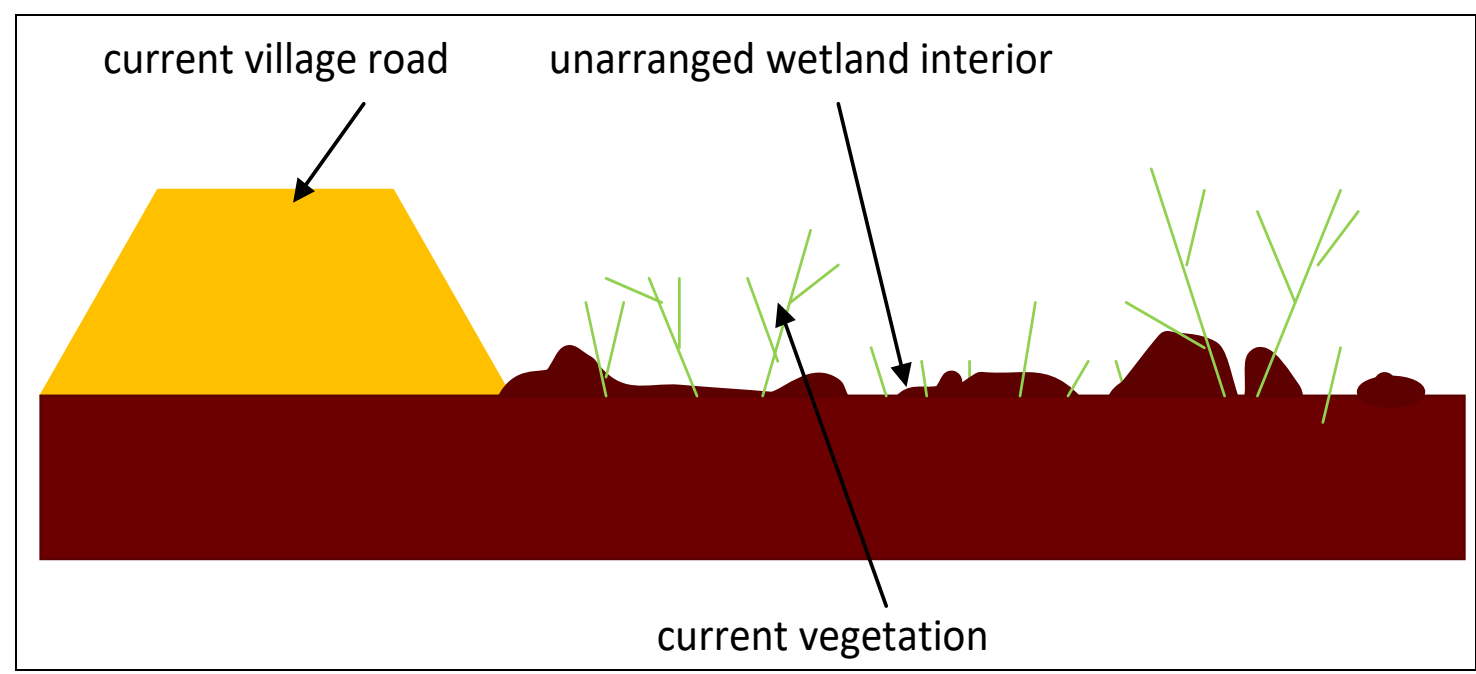

Figure 7: Surface where the wetland is to be built (cross section) - indicative scheme.

The process of habitat wetland arrangements consists of scraping a $30 \mathrm{~cm}$ layer of soil (removing all existing vegetation in the area) and levelling the internal surface (Figs. 7, 8 wetland arranged inside newly built earth dyke).

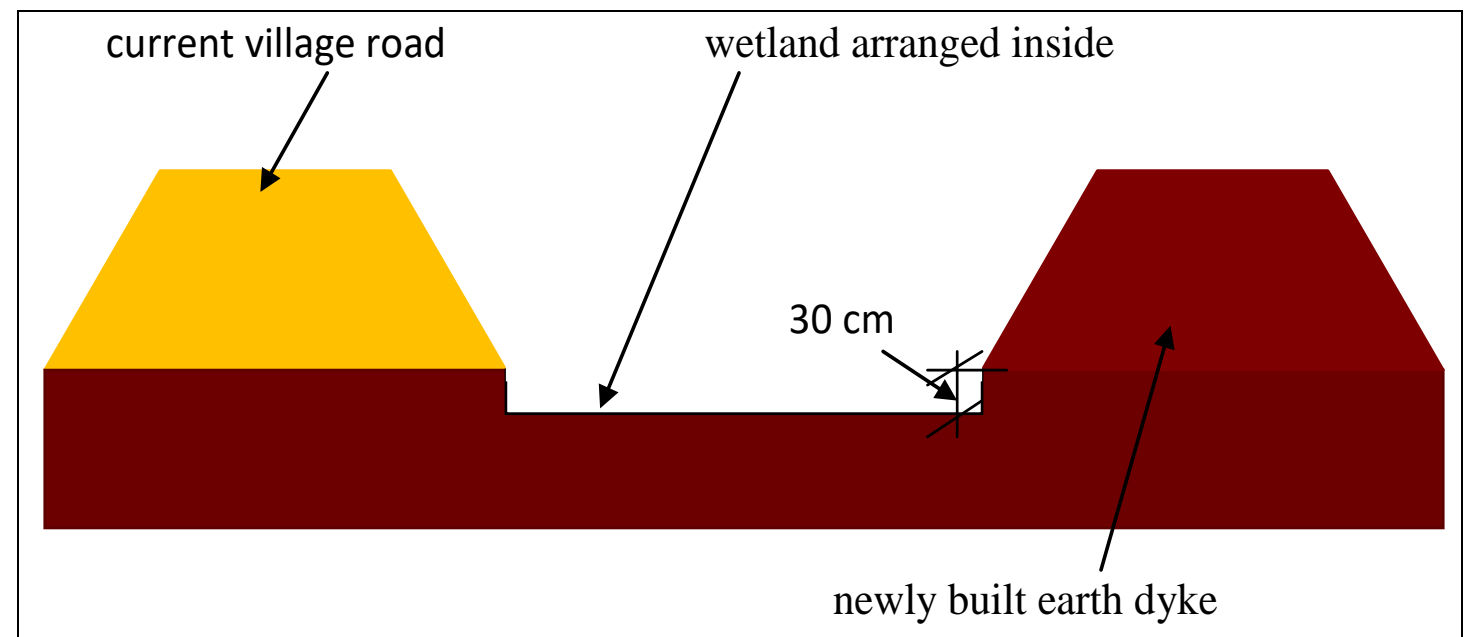

Figure 8: Construction of the wetland (cross section) - indicative scheme. 
In order for water to maintain a constant level of $1.0 \mathrm{~m}$, the newly created habitat should be dammed entirely with earth dikes of around $2.5 \mathrm{~m}$ height and $4.0 \mathrm{~m}$ thickness (Fig. 6) and continuously supplied with water. Creating or arranging a wetland requires ways to supply water and storing it so as to maintain a constant water level. The newly created wetland area will be supplied with water by tankers during its construction phase, and then the supply system shown below will ensure the water supply within the created wetland.

A main aspect is that the wetland water supply is achieved gravitationally and that excess water from the wetland will be directed into the Hârtibaciu River. Water captured from the Hârtibaciu River comes back to the same source. The need for access to water is due to the proposed wetland being $1.0 \mathrm{~m}$ deep, and where there will surely be some water loss through a series of processes such as infiltration and biological consumption, the highest quantity will be lost in the evaporation process.

Equipping the system with water level sensors and automatic valves reduces the cost of fuel system verification by specialists. If there are heavy rains, the water level in the wetland will remain constant due to the concrete channels built in order to handle the excess water and discharge it back into the Hârtibaciu River. The automatic valve allows flows of $10 \mathrm{l} / \mathrm{s}$ into the stainless steel pipe, regardless of the increase or decrease of the Hârtibaciu River water level.

\section{Description of the wetland water supply system}

Water supply to the wetland will be directly provided from the river upstream of Hârtibaciu bridge (approximately one km from the bridge). Captured water will be transported under pressure by a stainless steel pipe with an adjusted flow of $10 \mathrm{l} / \mathrm{s}$. The annual average flow of the Hârtibaciu River in the village of Alțâna is about one $\mathrm{m}^{3} / \mathrm{s}$, or approximately 1,000 l/s. Therefore, the undertaken flow (10 l/s) is not significant and will not affect the aquatic organisms or the abiotic structure of the Hârtibaciu River. This pipeline will be fitted with an automatic valve at its upstream end (Fig. 9) through which a flow of $10 \mathrm{l} / \mathrm{s}$ will be maintained in the pipe, regardless of water level fluctuations (water level increase or decrease) in the Hârtibaciu River. It is also proposed that the automatic valve be connected to a level sensor located on a gauge within the wetland. At the upstream end of the pipe, a metal grill will be installed in order to avoid clogging and blockage (Fig. 9). The pipeline is underground and circular-shaped, and will pass under the unpaved road on the bridge.

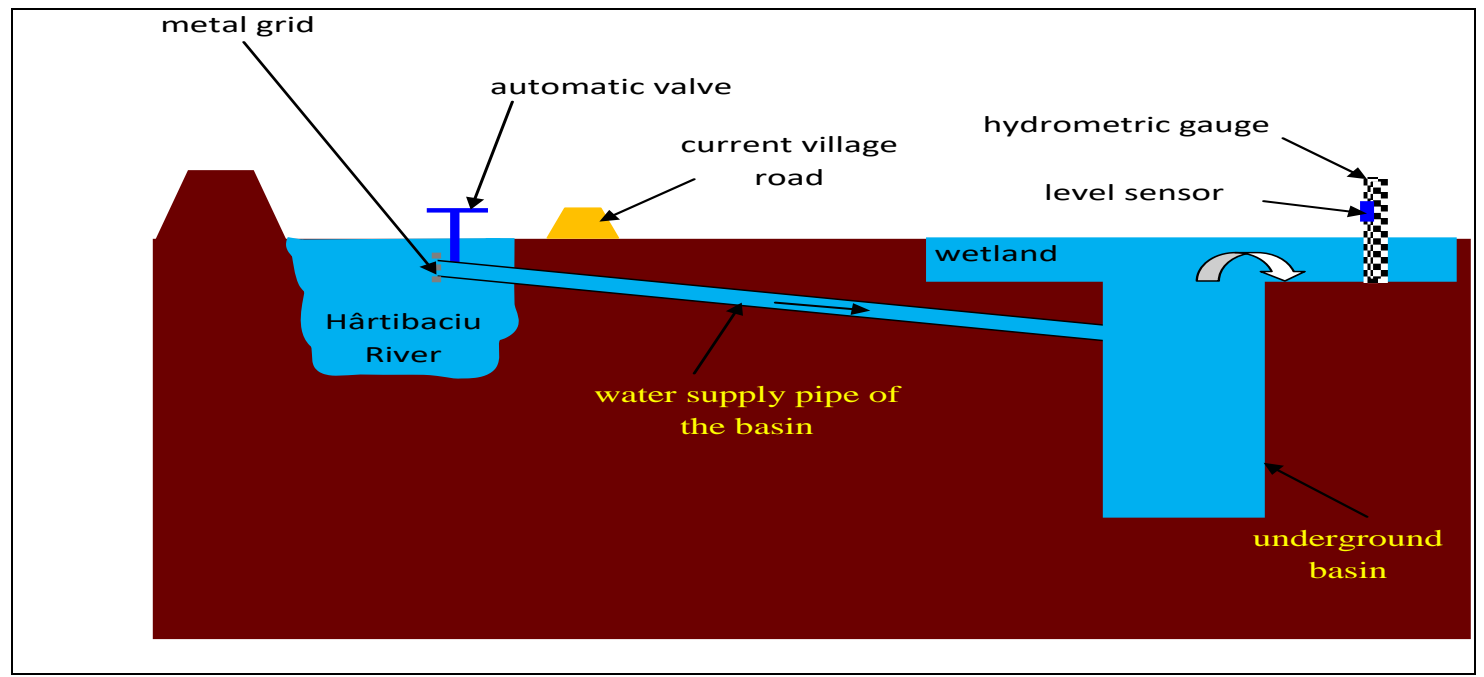

Figure 9: Schematic representation of the wetland location - indicative scheme. 
The water is then discharged into a basin built into the wetland with the following dimensions: $5.0 \mathrm{~m}$ depth, $5.0 \mathrm{~m}$ length and $6.0 \mathrm{~m}$ width. The wetland will be directly connected through a channel to another basin (pond) built with the following dimensions: $20.0 \mathrm{~m}$ length, $3.0 \mathrm{~m}$ height and $10.0 \mathrm{~m}$ width (Fig. 10). This basin will be used to propagate fish populating the Hârtibaciu River (chub, barbell, broad snout, loach, carp, perch, etc.). This pond has a direct connection with the Hârtibaciu River through a rectangular channel (Fig. 11). Water quality in the pond will be better than in the Hârtibaciu River because the wetland functions as a filter. In case of river pollution the pond will be suitable habitat for many creatures inhabiting the wetland.

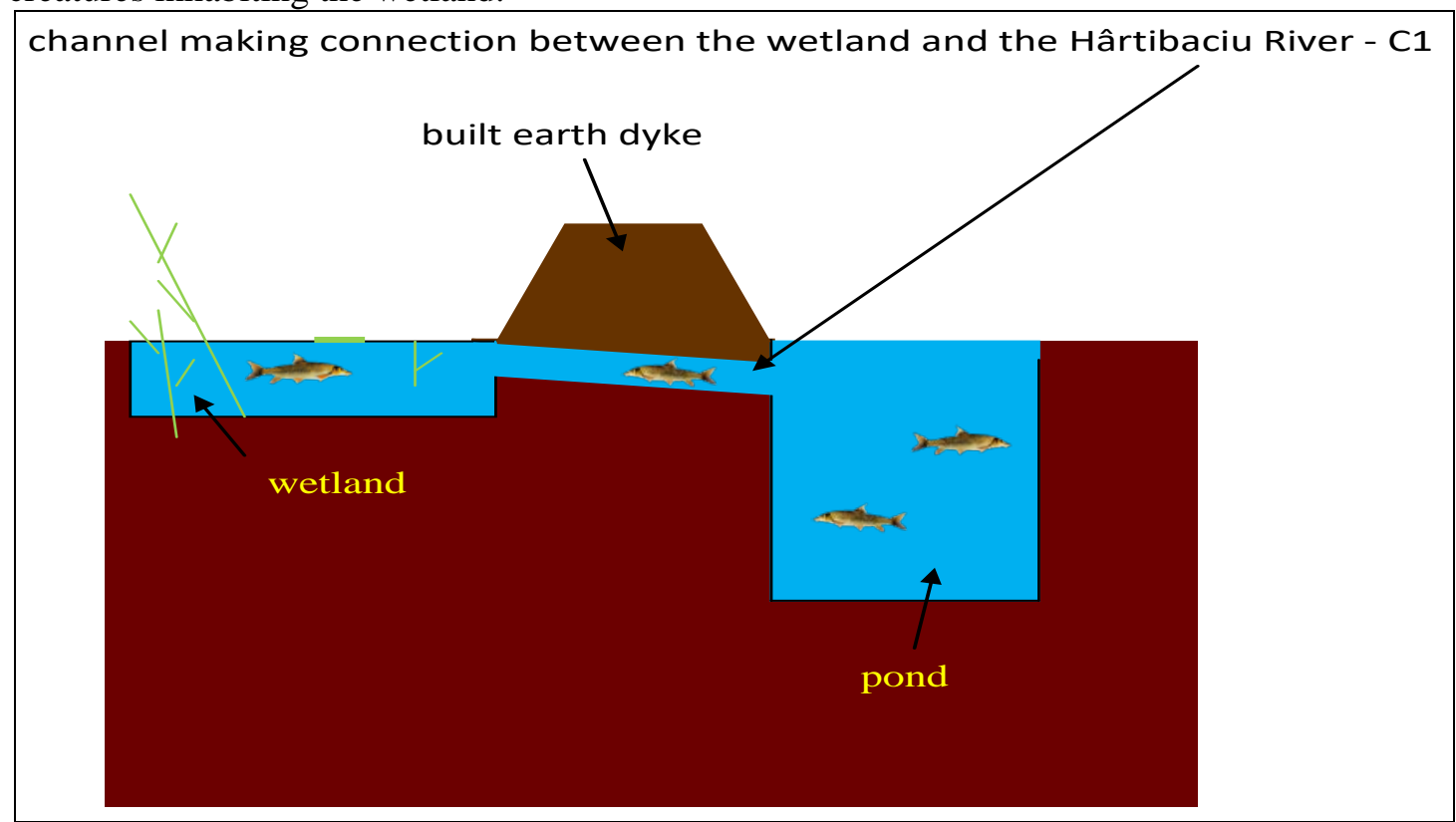

Figure 10: Positioning C1 channel - indicative scheme.

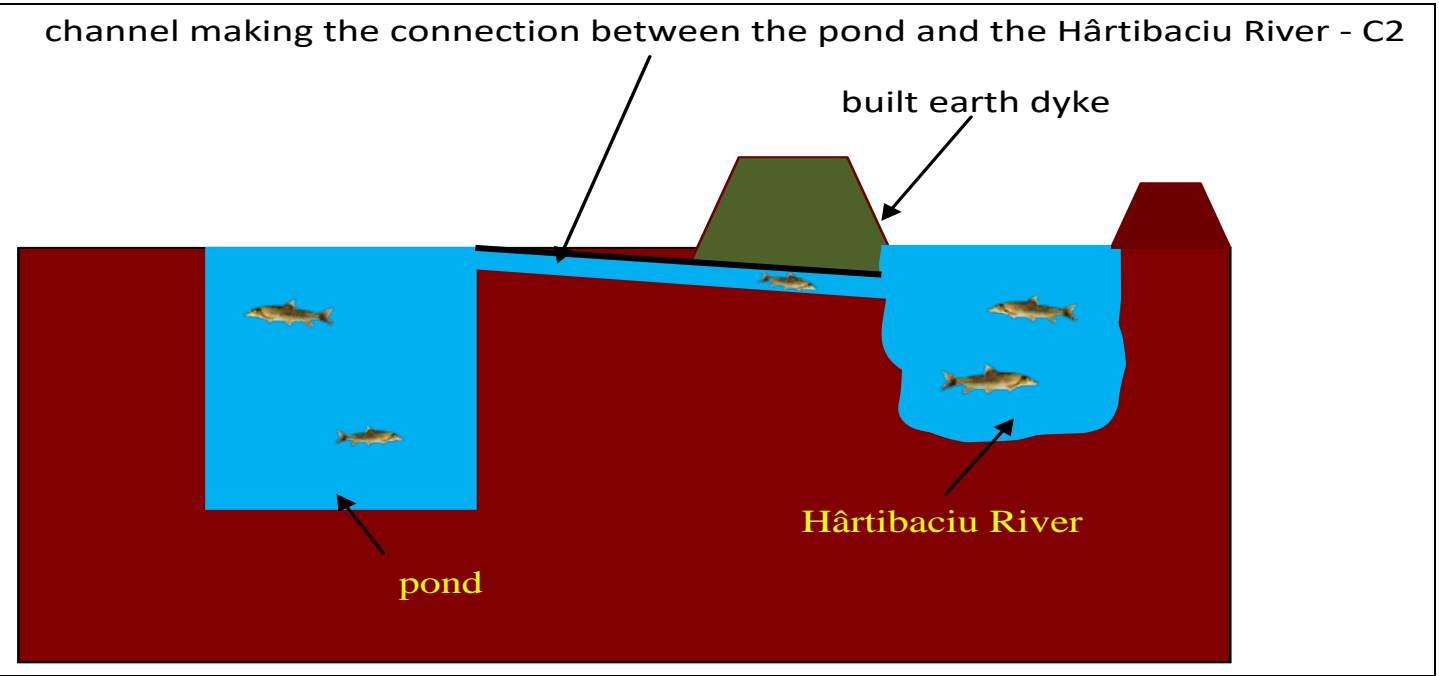

Figure 11: Positioning C2 channel - indicative scheme. 
After filtration has reduced pollution, they can return to the wetland. The two channels connecting the wetland and pond (C1) and the pond and the Hârtibaciu River (C2), will be equipped with mobile vertical grids driven by mechanical gears (Fig. 12), and will be made of concrete plated with wood piling and river stones (Fig. 13). Biologists, along with specialists, will monitor the proper functioning of the engineering components in the newly created wetland and will specify when to open and close the metal grids for fish to reach the wetland or the Hârtibaciu River. The two connection channels have different slopes: the channel connecting the wetland and the pond (C1) has a tighter slope favourable for all species to pass into the wetland, whilst the channel connecting the pond and the Hârtibaciu River (C2) has a slope which does not facilitate fish passage from the river up to the pond.

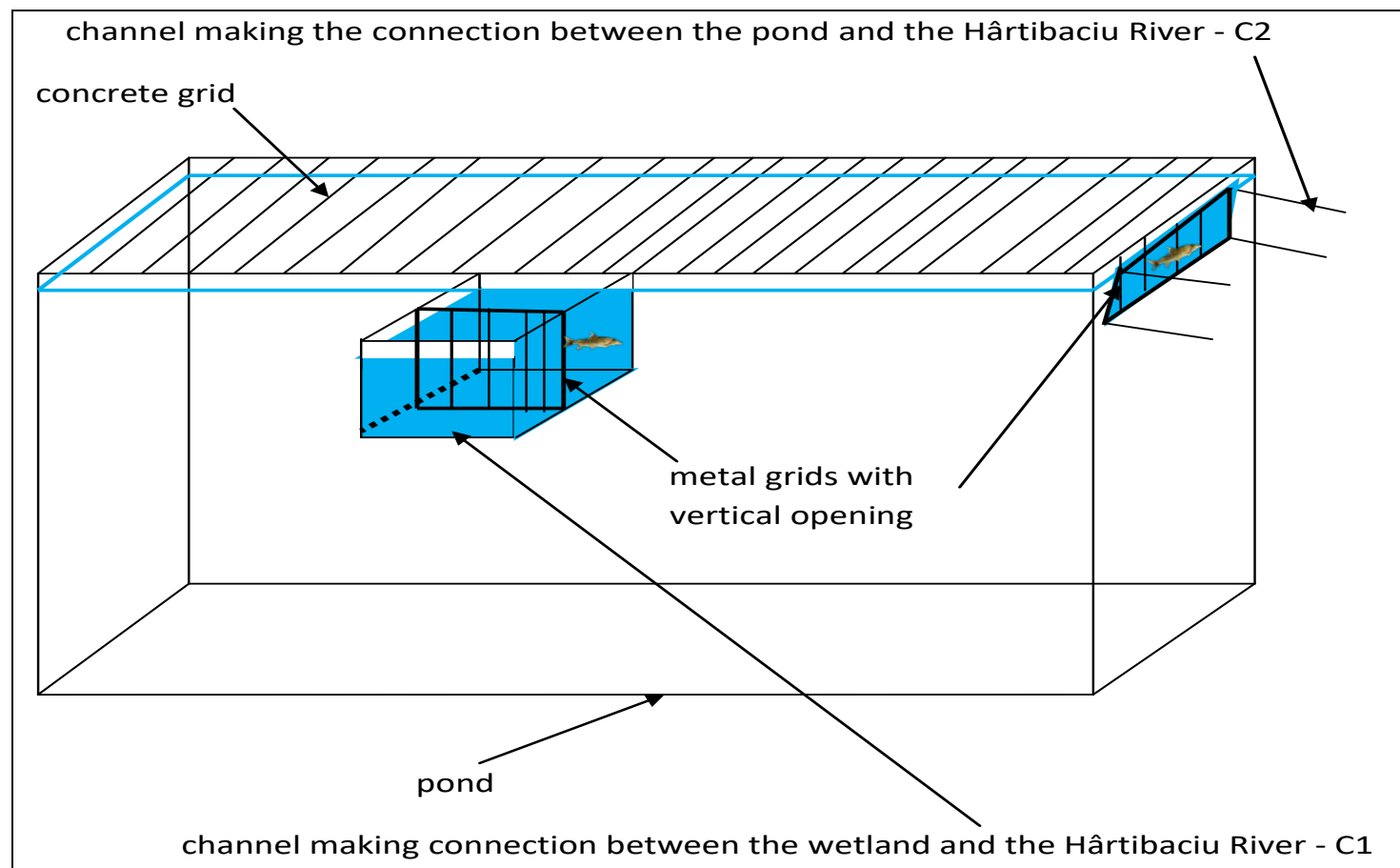

Figure 12: The positioning of the two channels C1 and C2 towards the pond - scheme.

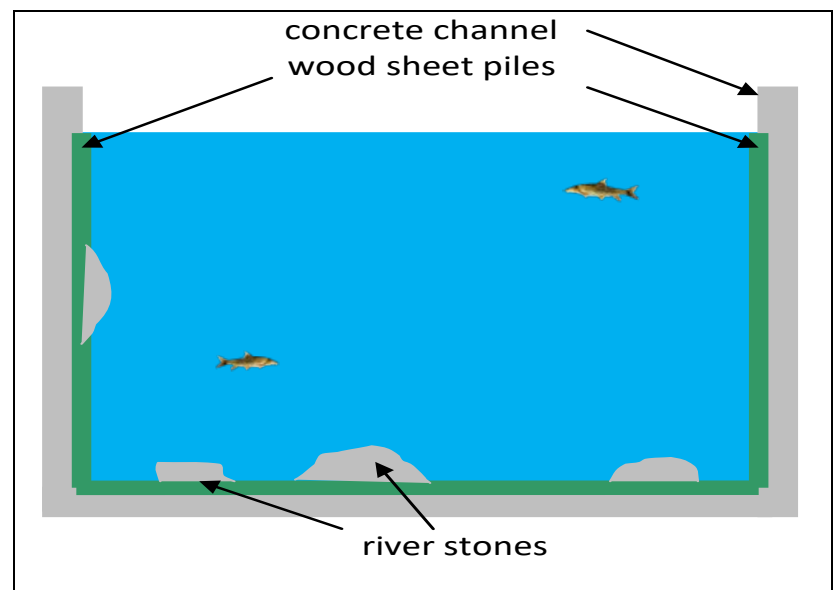

Figure 13: Concrete channel plated with wood piling and river stones - scheme. 
The second channel (C2) is strictly built for populating the Hârtibaciu River with different fish species. If the water level exceeds $1.0 \mathrm{~m}$, it would be advisable to build a concrete channel (sewer) in the existing dyke along the Hârtibaciu River, designed to take the excess water over $1.0 \mathrm{~m}$ in the wetland, which will then be discharged into the Hârtibaciu River (Fig. 14). We estimated that the sewer should be able to handle a higher flow rate of $10 \mathrm{l} / \mathrm{s}$.

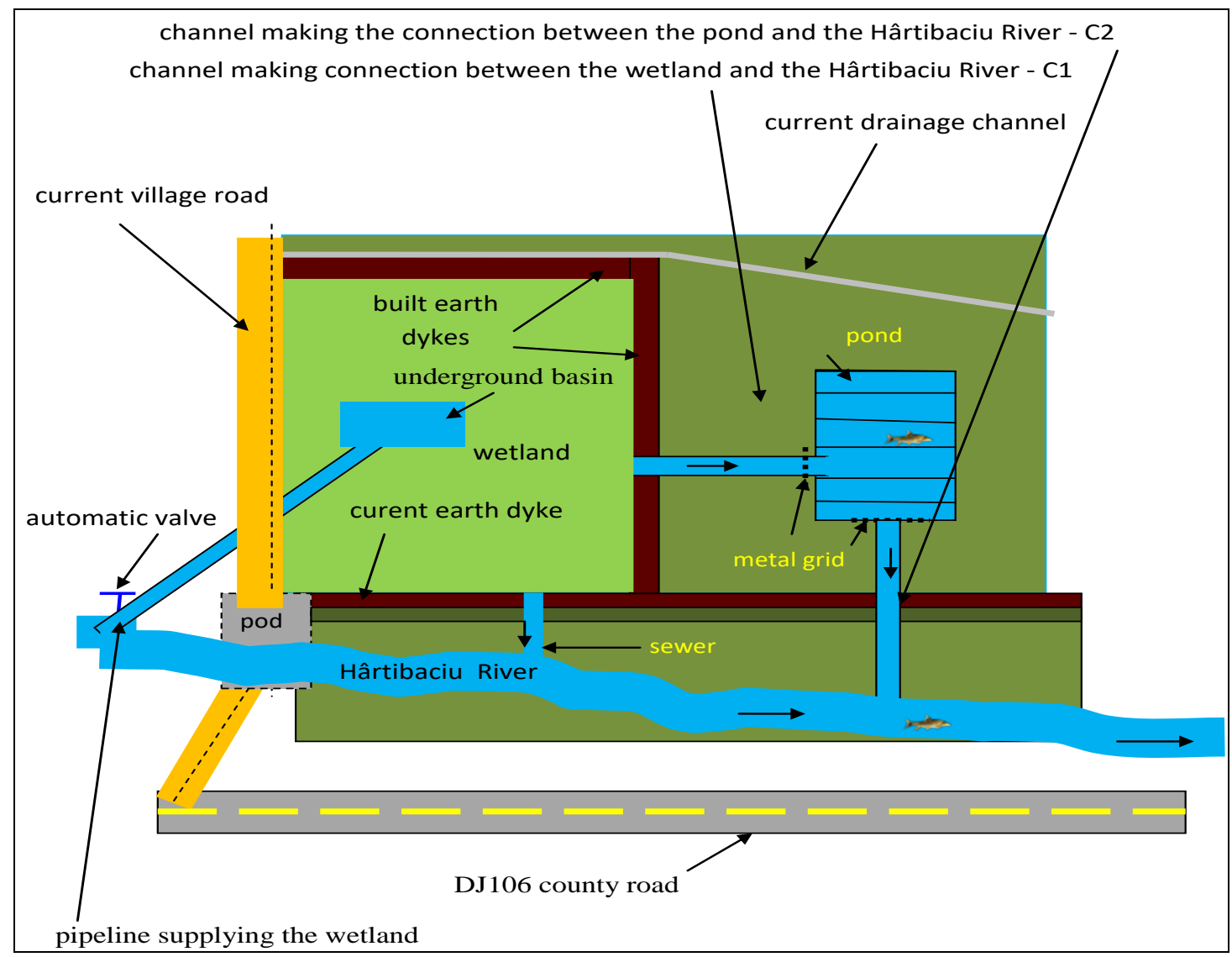

Figure 14: General scheme proposed for achieving wetland - indicative scheme.

An important aspect to stress is that the process to supply water to the wetland is achieved gravitationally, and the excess water in the wetland will be directed towards the Hârtibaciu River in a similar way.

\section{CONCLUSIONS}

All the fish species presently experience major human impacts along the Hârtibaciu studied sector, in the proximity of the Alţâna location.

The newly proposed constructed wetland sets in place the foundation for the rehabilitation of the lateral connectivity and the habitat quality for the single fish species of conservation interest sampled there Rhodeus sericeus amarus, and would increase the population numbers of this species.

The creation of the new proposed wetland would constitute an important buffer zone for fish, especially in the dry and cold (with frozen periods) seasons. 


\section{REFERENCES}

1. Bănăduc D., Rey S., Trichkova T., Lenhardt M. and Curtean-Bănăduc A., 2016 - The Lower Danube River-Danube Delta-North West Black Sea: A pivotal area of major interest for the past, present and future of its fish fauna - A short review, Science of the Total Environment, 545-546, 137-151.

2. Bănărescu P. M. and Bănăduc D., 2007 - Habitats Directive (92/43/EEC) fish species (Osteichthyes) on the Romanian territory, Acta Ichtiologica Romanica, II, 43-78.

3. Curtean A., Sîrbu I., Drăgulescu C. and Bănăduc D., 1999 - Impactul antropic asupra biodiversităţii zonelor umede din bazinul superior şi mijlociu al Oltului, Edit. Universităţii “Lucian Blaga” din Sibiu, ISBN 973-651-003-4, 103. (in Romanian)

4. Orlov O. and Vovk O., 2011 - Influence of the alluvial deposits on the soil properties of the floodplain of the foothill current of the river Tysa, Transylvanian Review of Systematical and Ecological Research, 11, Edit. Universităţii “Lucian Blaga” din Sibiu, 59-64.

5. Peacock C., 2003 - Rivers, floodplains and wetlands: connectivity and dynamics, Review of the importance of floodplain connectivity and dynamics for riverine biodiversity, including implications for definitions of ecological status under the Water Framework Directive, 64.

6. Schneider-Binder E., 2008 - Importance of floodplains and floodplain wetlands along the lower Danube with special regard to phytodiversity, Transylvanian Review of Systematical and Ecological Research, 6, Edit. Universităţii “Lucian Blaga” din Sibiu, 59-70.

7. Schneider-Binder E., 2009 - Floodplain forests along the lower Danube, Transylvanian Review of Systematical and Ecological Research, 8, Edit. Universităţii “Lucian Blaga” din Sibiu, 113-136.

8. Sîrbu I., Sárkány-Kiss A., Petrescu M., Lazăr B. and Buian, G., 1999 - Contributions to the knowledge of the freshwater mollusk fauna from the upper and middle basin of the Olt River (Romania), Transylvanian Review of Systematical and Ecological Research, 1, ISSN 1841-7051, ISBN 973-9410-69-3, Edit. Universităţii “Lucian Blaga” din Sibiu, 111-122. 